\title{
What is Meant by 'Repair' when Claiming Reparations for Colonial Wrongs? Transformative Justice for the Dutch Slavery Past
}

Que signifie "réparer " lorsqu'on demande réparation pour des torts coloniaux? Les demandes de justice transformative pour le passé esclavagiste des Pays-Bas ¿Qué significa "reparar" cuando se pide reparación por daños coloniales? Los pedidos de justicia transformativa por el pasado esclavista en los Países Bajos o que significa "reparo" quando se pede reparação pelos prejuízos coloniais? A justiça transformativa em relação ao passado escravista dos Países-Baixos

Nicole L. Immler

\section{(2) OpenEdition}

\section{Journals}

Electronic version

URL: https://journals.openedition.org/slaveries/5089

DOI: 10.4000/slaveries.5089

ISSN: 2540-6647

Publisher

CIRESC

Electronic reference

Nicole L. Immler, "What is Meant by 'Repair' when Claiming Reparations for Colonial Wrongs?

Transformative Justice for the Dutch Slavery Past", Esclavages \& Post-esclavages [Online], 5 | 2021,

Online since 25 November 2021, connection on 05 January 2023. URL: http://

journals.openedition.org/slaveries/5089; DOI: https://doi.org/10.4000/slaveries.5089

This text was automatically generated on 5 January 2023.

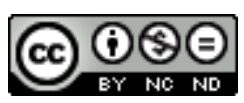

Creative Commons - Attribution-NonCommercial-NoDerivatives 4.0 International - CC BY-NC-ND 4.0 https://creativecommons.org/licenses/by-nc-nd/4.0/ 


\title{
What is Meant by 'Repair' when Claiming Reparations for Colonial Wrongs? Transformative Justice for the Dutch Slavery Past
}

\author{
Que signifie "réparer " lorsqu'on demande réparation pour des torts coloniaux? \\ Les demandes de justice transformative pour le passé esclavagiste des Pays-Bas \\ ¿Qué significa "reparar" cuando se pide reparación por daños coloniales? Los \\ pedidos de justicia transformativa por el pasado esclavista en los Países Bajos \\ O que significa "reparo" quando se pede reparação pelos prejuízos coloniais? A \\ justiça transformativa em relação ao passado escravista dos Países-Baixos
}

Nicole L. Immler

\section{Introduction: The Transformative Justice Paradigm}

1 The history of slavery has gained prominence in Dutch public consciousness. In 2002, the first National Monument to the Dutch Slavery Past was inaugurated in Amsterdam, unveiled by Queen Beatrix. Since then the annual commemoration of the abolition of slavery in the former Dutch colonies of Suriname and the former Dutch Antilles (six islands in the Caribbean Sea) has developed from a local community affair into an event broadcast live on national television. While in 2013 the $150^{\text {th }}$ commemoration of the abolition of slavery in 1863 was held in the presence of the new King Willem Alexander, in 2020 the commemoration went beyond the symbolic: it was followed by a debate in the Dutch parliament on racism and the question 'whether an apology is needed'. It was a debate in which the Prime Minister rejected responsibility ('can you hold people responsible for this today?'), while also making the assumption that reparation would 'close the matter'. Ministers however stressed the importance of 'bearing witness to the past and acknowledging our history,' appointing an Advisory Board Dialogue Group on 
the history of slavery to organise a public debate about the Dutch history of slavery and its impact on today's society, in order to stimulate 'a broader recognition of this shared past'.

The last two decades have seen a shift from a 'particularized sub-memory among parts of Caribbean Dutch communities, to an issue of public debate and national Dutch concern' (Jones 2020: 280). One can observe how the Dutch public view is shifting from 'their history' to 'our history,' from a debate that mainly revolved around 'cultural heritage' within the community of descendants of enslaved people themselves, to a broader discussion of the colonial legacy of our society in terms of 'misrepresentation,' 'institutional racism' and 'socio-economic inequality' (Immler 2021a). While the current public and political debate in the Netherlands focuses on the value (and the cost) of an apology, in Afro-Caribbean and Surinamese communities a much broader notion of repair circulates, focussing on structural injustices. This article engages with those subaltern voices, presenting empirical data 'from below, ${ }^{1}$ and locating the Dutch case in current debates in the field of Transitional Justice to explore the reparative quality of recognition disputes and procedures.

\section{From Transitional Justice to Transformative Justice}

3 Transitional Justice has been called 'one of the defining global movements of our time' (Neumann \& Thompson 2015: 23). It is a field that explores the long-term effects of human rights violations and the instruments developed to deal with past atrocities, such as criminal trials, historical commissions, commemorations, apologies and reparations (Miller \& Kumar 2007). Yet, as critics say, the field is based more on faith than facts (Thoms, Ron \& Paris 2010) and is more devoted to bringing those reparatory measures into place than to monitoring their effects at individual, communal, and social levels (Olsen, Payne \& Reiter 2010). While Transitional Justice policies have been implemented in numerous post-conflict cases, what little knowledge we have about the effects of these measures leads to contradictory findings, indicating that they are often ambiguous and disappointing (Gready \& Robins 2014). Individual needs often diverge from societal ones (Hamber 2000), and recognition politics can even reproduce the trauma they aim to heal by making people feel excluded and stigmatized instead of socially integrated (Fassin \& Rechtman 2009).

4 Consequently scholars proclaimed the need for more interdisciplinary and empirical knowledge 'from below' (McEvoy \& McGregor 2008; Lundy \& McGovern 2008). ${ }^{2}$ The last decade has seen a specific call for a 'new agenda for practice,' asking for a transition from Transitional Justice to Transformative Justice. This is a call to develop from the bottom-up a concept of justice that is more 'transformative' (Gready \& Robins 2014: 339; Gready \& Robins 2018), specifically challenging 'unequal and intersecting power relationships and structures of exclusion at both the local and the global level' (Gready \& Robins 2014: 340).

While one can observe a new transformative paradigm emerging within Transitional Justice more generally (Daly 2002; McAuliffe 2017), and specifically in regard to reparations (Yepes 2009; McGonigle Leyh \& Fraser 2019), it remains unclear what 'transformation' means in theory and in practice: 'is it about individual or societal transformation-or both? Can an individual even be transformed if their society is not? Who gets to determine when someone's life or society has been transformed?' ${ }^{3}$ The 
transformative justice approach is considered as a critical approach to Transitional Justice which, by revealing shortcomings and misguided rhetoric, supports more ambitious, emancipatory and radical visions for change.

While some doubt whether Transitional Justice-used generally in transition and postconflict situations-can address historical injustices such as colonialism and slavery that caused long-term social, political and economic effects, scholars such as Maeve McKeown have convincingly argued that the slavery reparation case is instructive as it defies 'conventional thinking about reparations in the structural injustice literature' (McKeown 2021: 2). Her argument is against a recent trend in Transitional Justice that embraces a forward-looking responsibility approach to reach out beyond the backward-looking liability approach (Lu 2017), but in favour of the need to combine both.

7 This article aims to contribute to this debate by exploring the following question: how could reparations-fundamental in the debate around the acknowledgment of the slavery pastfacilitate transformative justice? It is crucial to gain a better understanding of what is meant by 'transformative justice,' first in theory and then in practice. I show first how in the last decade in Transitional Justice literature, ideas about reparations have changed and elaborated on the idea of transformative reparation. I then introduce Lisa Laplante's model of a justice continuum (2013/2015), which enables me to clarify the kind of justice that we are talking about in the Dutch case. This article reflects on different understandings of justice, describing the reparation claims addressing the past of Dutch slavery articulated by various groups in and outside the Netherlands, and some of the institutional responses. It will be argued that we would come closer to what memory and reparation activists are aiming at if we made the notion of 'social repair' more central to the debate, rather than focusing on 'apology' and 'reparations'. At the same time this notion of repair might allow a broader part of Dutch society to identify with particular reparatory instruments as part of a joint struggle for a fairer and more equal society for all citizens.

\section{Transformative Reparations}

8 For some time a quite narrow idea of reparations has dominated the Transitional Justice field: the traditional aim of reparations was to "place the victim back in the position they would have been in had the harm not occurred' (McGoningle Leyh \& Fraser 2019: 39). More recent transformative reparation theories are rooted instead in 'the belief that it is ineffectual to place marginalised victims back in positions of marginalisation following serious harm,' aiming to address also 'socio-economic disparities and unequal power structures' to transform the lives of victims and the power structures that sustain unequal relationships (Ibid.). The label transformative reparations incorporates a wider range of human rights (such as socioeconomic rights), moving beyond individual approaches to address deeper institutional and structural problems. According to McGoningle Leyh and Fraser (2019: 57), whether reparations serve as a 'catalytic device' for transformation depends mainly on two key factors: 'the extent to which victims and victim communities organise themselves into effective networks for change, and whether the reparations process is complemented by broader state actions addressing structural reforms'. They see inclusive participatory processes ('requested by and designed with victims and victim communities') and a clear mandate 
for the state and/or other 'implementing authority' as vital if the transformative potential of reparation is to be realised. This means 'that other, more permanent, changes and reforms need also to take place'; therefore they stress the need for a 'shared, common understanding of the transformative goal' (McGoningle Leyh \& Fraser 2019: 56, 58 and 59). To illuminate the notion of transformative reparation it helps to engage with Lisa Laplante's 'justice continuum model' (2013; further extended: 2015) that identifies various aims for justice.

\section{'Justice Continuum Model'}

9 Reparations have hitherto gained little conceptual attention in transitional justice scholarship. 'Reparations can and should be viewed through a lens of justice'. With this dictum Laplante (2013: 68) made an important intervention in the field, by asking which reparations contribute to what kind of justice. As the last decade has seen a move from a narrow towards a more comprehensive conception of reparations, it has become necessary to identify the different notions of justice involved. Laplante argues that being more aware of the type of justice that reparations aim at would help to manage the expectations of victims, as well as to monitor the effects of the measures taken. ${ }^{4}$ This so-called 'justice continuum model,' encompasses four types of 'justice aims' ranging from a narrow to a broader conceptualisations of justice, from a 'minimalist' (no further harm) to a 'maximalist' (full range of justice aims) approach: from reparative justice (to compensate a damage or harm through material compensation to "place the victim back in the position they would have been in had the harm not occurred'), restorative justice (to repair a damage by restoring the dignity of both offenders and offended), and civic justice (to ensure participation and inclusion in society), to socioeconomic justice (to remedy historic socioeconomic inequalities and re-distribution).

Whereas the reparative and restorative justice approach focuses on repairing the past by addressing the specific needs of victims/survivors and the responsibilities of offenders and the community they belong to, the civic and socio-economic approaches are more future-oriented, addressing the structural nature of injustices and aiming at a more transformative process, requiring the state to play a more active role.

11 Compared to reparative and restorative justice that relate to processes of microreconciliation and personal healing, civic justice relates to a macro-level civil reconciliation process that seeks 'to mend the relationship between the state and its subjects' (De Greiff 2006: 460-2). The civic justice approach remedies political inequalities and integrates the institutional perspective. 'This institutional response is often the earliest and most visible manifestation of the deepest values of the new order. As such, it can begin the transformation of the society at large' (Daly 2002: 75f.). This stresses the fact that 'having formal legal equality' is not enough but requires that the excluded or marginalised be more pro-actively included in advance, and views reparations as part of wider 'social, political, and judicial reform processes,' which together are intended to contribute to 'social reconstruction'. Following Daly, transformation is less about the goal, a specific political-legal change, than about the process: 'tailored to the time and place' in which transitional justice instruments operate, and requiring an ongoing commitment.

While reparative justice approaches deal with the calculation of specific damages, socioeconomic justice remedies historical social and economic inequalities, recognising 
the links between transitional justice and development, and prioritizing (re)distribution (De Greiff \& Duthie 2009). Socioeconomic justice blends 'reparation for past violations or crimes' with that of 'distributive justice in the future' (Lambourne 2009: 41). This distributive justice aspect of reparations is often stressed in the US literature on slavery reparations, proposing monetary transfers from whites to blacks (Brophy 2006). As the time-gap makes it difficult to assign causal relationships of guilt, the proposals for large-scale redistributive transfers are often justified as a way of reducing substantial socioeconomic inequalities through, for instance, investments in a more equal infrastructure such as healthcare or education. ${ }^{5}$

Typologizing various justice theories, Laplante argues that one model is not better than another. She stresses instead that justice needs are plural and dependent on set objectives. In line with ideas of a pluralist justice approach, Laplante stresses the importance of specifying justice so that it resonates with those intended beneficiaries who are claiming justice.

14 Laplante's justice continuum model refines the more popular distinction made in Transitional Justice between backward and forward-looking reparations; prominently described in the case of slavery by Roy Brooks (2006), who distinguishes two competing models: the settlement model or so-called tort model, which is backward-looking and victim-survivor-descendant focused, designed to financially compensate victims for their demonstrable loss; characterized by statute of limitations, restitution law, and the calculation of damages. The atonement model by contrast is forward-looking and offender-focused; the offender-descendant reclaims his/her moral status by initiating conditions that help repair the broken relationship with the victims; this is characterized by an apology and reparations that give substance to it. Translated into the reparation question this means, instead of seeing 'black reparations as a campaign for cash reparations, white punishment or white guilt,' the aim is 'to repair the broken relationship between the government and the victims of that atrocity' via an apology, reparations and a commitment to racial equality' (2006: 155f). ${ }^{6}$

15 Although the models mentioned differ to some degree, for the purpose of this article it is relevant to see justice on a continuum-minimum towards maximum, backward towards forward approach-to identify what kind of justice we are referring to. Laplante's model will allow us to identify which ideas of (reparatory) justice are articulated in the debates on the Dutch slavery past. Moreover, adding the lens of transformative reparations will finally allow for a clearer distinction between reparative/restorative justice and civic/socio-economic justice.

\section{Stances on Justice for the Dutch Slavery Past}

The models described above show the options a government and a society have for giving form to a recognition and reparation process, which deals with (historical) injustice. Next, I will show the various steps taken in the Netherlands to address its slavery past, mapping the reparation claims and actions of different actors and then locating them on the continuum scale of justice described above. 


\section{Memory Politics: Global-Local dynamics}

17 Via the advocacy activities of Dutch Caribbean communities, efforts to combat the silence around the Dutch slavery past gained momentum in the 1990s. At the beginning the commemoration of 1 July, Keti Koti ('broken chains') was foremost an identitybuilding community event for the 'Afro-European Dutch'. Inspired by US African American identity politics, the prefix 'Afro' to refer to the 'self' (Afro-Antillean, AfroSurinamese) replaced previously more common terms such as 'Creoles' or 'peers/ rijksgenoten' (Jones 2012: 65). This community event developed into a public event after eighteen Dutch Caribbean organisations formed the National Platform for Dutch Slavery History recognised by the Dutch government as 'a partner in dialogue' about creating a national monument and institute (Jones 2020: 281). The National Monument to the Dutch Slavery Past was unveiled by Queen Beatrix in July 2002 in Amsterdam. Interior Minister Rogier van Boxtel expressed 'deep remorse' on behalf of the Dutch government for slave trade and slavery as a core business of the West India Company, following up on a gesture which he had made some months earlier in 2001 at the UN World Conference against Racism, Racial Discrimination, Xenophobia and Related Intolerance in Durban, South Africa (known as the Durban conference). This was a foundational conference for the opening of reparation debates around slavery as a crime against humanity, acknowledged as such for the first time. In the same year, Crown Prince Willem Alexander used similar words of 'deep remorse' on his state visit to Ghana, once a crucial Dutch colony in the system of the Trans-Atlantic slave trade.

Since then the Dutch government, followed by a number of Dutch cities, has made various gestures of recognition, such as support for a National Institute of Dutch Slave History and Heritage (NiNsee), ${ }^{7}$ expressions of regret by dignitaries, the establishment of several monuments, inclusion of slavery as a theme in the historical canon, a series of exhibitions (in 2021 even in the Rijksmuseum in Amsterdam), radio and television programmes, and a stream of historical reports commissioned by cities to explore their involvement in slave trade and slavery. On 1 July 2021 the Mayor of Amsterdam apologized on behalf of the city government for its continuity with the perpetrators of slavery; having been actively involved 'in the commercial system of colonial slavery and the worldwide trade in enslaved people'. For observers it feels 'good to hear,' but they add: 'It must not end here'. A mood also reflected in the social media.

19 All such institutional actions were responses to preceding movements for social emancipation, and to community or scholarly activism, ${ }^{8}$ which since 2011 had developed into a broader anti-racism movement. ${ }^{9}$ Thanks to the debate over Black Pete -a racially charged blackface character in the annual Saint Nicolas tradition on 5 December-and the Black Lives Matter movement, the history of slavery has moved in the last decade from the back rooms of historians, economists and psychologists into the broader public space-manifest, for instance, in urban spaces, museums and mainstream media. Massive police violence against 'Black Pete is racism' activists (Kickout Zwarte Piet) and public trivialisation of slavery made these distinctive traces of the past unmistakably visible. This led to substantive shifts in the way the history of slavery and its legacy is narrated: from national to local history, from statistics and economical figures to family stories, from incidents to structural violence, from an us/ them logic to a shared and entangled history approach, from a victim to an actor and from a trauma to a citizenship perspective (for more details see Immler 2021a). These 
shifts in public storytelling have also influenced the ways in which recognition and reparation claims and entitlements are discussed.

\section{From Trauma Narratives to Struggles for Rights} was manifest in a variety of terms. In the 1970s and 1980s it was about community building in the Netherlands and the legal, social and socio-economic dimensions of citizenship (Oostindie 2011). Slavery as a history of pain and shame was seen as a private history, actively commemorated within Caribbean Dutch diaspora organizations, but taboo in public discussion ('I come from a Surinamese family of teachers. [...] [B]y having a good education, my Creole family tried to resemble the white upper class as much as possible. There was no reason at all to learn about slavery; people were ashamed of it.'). ${ }^{10}$ Only in the 1990 s did advocacy for the public recognition of transatlantic slavery begin: 'Inclusion was no longer simply defined as an improvement in people's socio-economic and legal status (residence and citizenship status), but also as a public recognition of slavery and its racialized afterlives' (Jones 2020: 281). (Eyerman 2001), characterized by the way such terms as "post traumatic slave syndrome' were used not only by black descendants from the (former) Dutch colonies to describe their individual or group condition, but also by mainstream media. However, to frame the call for recognition as a call for the acknowledgment of trauma, both dismiss the political nature of those demands, which were aimed at discussing structural legacies. ${ }^{11}$

This cultural trauma terminology also coloured the $150^{\text {th }}$ anniversary of the abolition of slavery in 2013. Anthropologist Francio Guadeloupe (2014), describing those commemorative events in the Netherlands, observed the prominence of what he called 'a cultural trauma trope' used by many Dutch Afro-Caribbean intellectuals to highlight the structural damage done to the community. Foregrounding notions of cultural trauma in their claims for redress by the Dutch government, they argued that their community has been 'severely handicapped' by the effects of the trans-Atlantic slavetrade on a 'cognitive and affective level'. They sought official apologies and financial compensation to restore their dignity and to repair 'the socio-economic discrimination and structural racism they face'. Guadeloupe-himself grounded in Caribbean culture and scholarship-recalled by contrast that from the start the struggle about reparations had been about citizenship, material progress and legal equality; a view more common in the Caribbean, where the commemoration of the abolition of slavery is first and foremost a celebration of the struggle for freedom. Consequently Guadeloupe interpreted past and contemporary struggles against the effects of transAtlantic slavery as an expression of the permanent 'revolutions of subjugated peoples to create a more just society and a fairer world' (Guadeloupe 2014: 115).

This 'revolution narrative' as Guadeloupe has called it, principally present in the work of Caribbean historians (Trouillot 1995), ${ }^{12}$ describes how abolitionist struggles like the Haitian Revolution and other anti-slavery movements laid the foundations of the struggle for reparations today (Sheperd 2018; Beckles 2013). In the Netherlands this 'revolution narrative' has only been foregrounded in recent years, reinforced by the 
Black Piet struggles and the Black Lives Matter movement: instead of 'enslavement,' descendants remember their ancestors rather as 'fighters' for their freedom and against a system of oppression and exploitation. In the Keti Koti public lecture in 2020, historian Karwan Fatah-Black reminds us that the crucial Haitian slave revolt of 17911804 was not just the work of the abolitionists or the enlightenment thinkers who made abolition a reality, but the mass resistance of black people themselves: 'without black resistance liberal democracies would not have been achieved. The history of the AfroAtlantic Diaspora is not only part of who we are, it is the measure of our success in sharing health, wealth, justice and education equally' (Fatah-Black 2020). This revolution narrative-embodied in practices such as marronage-goes back to a tradition of Black radicalism in the Caribbean, such as Garveyism and Rastafarianism, both with notions of reparation rooted in their collective Pan-African struggle to bring about social change. ${ }^{13}$ Memories of slavery and self-identifications as 'Afro-European Dutch' turned into advocacy for more equal citizenship (Jones 2020: 284). This shift from the trauma to the revolution narrative meant that alongside 'victims asking for recognition' we also see 'citizens demanding their rights'.

\section{From Aid to Reparatory Justice Claims}

The thinking of Dutch memory and reparation activists about reparations was over the last decade substantially shaped by two events: the claims for reparation put forward by the CARICOM countries, consisting of 15 Caribbean governments, against the formerly colonizing powers (2013), and the International Decade for People of African Descent (2015-2024) ${ }^{14}$ proclaimed by the UN General Assembly. ${ }^{15}$ Both revisited the declaration of the Durban Conference (2001), ${ }^{16}$ which had broadened and deepened global and local thinking about redress for slavery and colonialism; in so doing, they moved claims for reparation from specific historical injustices on the national level towards a struggle for more social justice on a global one.

In 2013 the CARICOM countries launched a 10-point plan (Beckles 2013; Scott 2014; McKeown 2021), a reparation claim against the agents that had historically harmed the region: the European governments of France, the United Kingdom, Spain, Portugal, Norway, Sweden, Denmark and the Netherlands. This claim sought reparatory justice for communities descended from slavery, the transatlantic slave trade, and genocide of indigenous people. The 10-point plan exemplifies a comprehensive reparatory justice approach: it covers a formal apology from Europe's former colonial powers and debt cancellation, repatriation (settlement in Africa for 'those persons who wish to return'), indigenous peoples development programme, cultural institutions, healthcare, illiteracy eradication, African knowledge programme psychological rehabilitation, and technology transfer. ${ }^{17}$ The 10-point plan aims at more than a debate about national guilt, demanding a kind of European response:

The CARICOM Nations, ancestral homes to the world's first complete slave-based economies, have established National and Regional Commissions in order to engage the nations of Europe, the owners and operators of these slave economies, in a diplomatic dialogue designed to rebuild trust and respect within the framework of reparatory justice... It calls upon the nations of Europe to return to the scene of these crimes and to participate in remedial development work that will enable African descendants to free themselves of the cultural and economic shackles that remained in place after the formalities of Emancipation. ${ }^{18}$ 
these words Hilary Beckles, Chair of the CARICOM Reparations Commission (CRC) and Vice Chancellor of the University of the West Indies, addressed the UN General Assembly in New York in December 2014, when the International Decade for People of African Descent was declared. Whilst Beckles detailed each European nation's responsibility (such as the Dutch: 'they were first to develop the trade in enchained African bodies as a modern, global, corporate enterprise'), he envisages collective action: "All of Western Europe combined with their "American" colonies created the cradle of western financial modernization based upon the most lucrative sustainable investment of all times-the enchained, enslaved African body as commercial property'. Ending the silence is seen as beginning to engage in reparatory justice; at the same time the CARICOM 10-point plan codified the vocabulary for doing so.

'Reparations is about the right to redress and repair, it's not about begging. We want to destabilize the narrative of aid and talk about real development,' says CARICOM's Reparations Commission Vice-Chair Verene Sheperd. ${ }^{19}$ The claim becomes more radical when rephrased by historian David Scott (2014: ix): 'Caribbean debt is the other side of European theft [...] the "persistent poverty" of the Caribbean has been a constituting condition for ill-gotten European prosperity... the two-the debt and the theft-are internally, not accidentally, connected'. For Sheperd (2018), this reparatory approach is not just about transforming problematic economical interdependencies, but is also about ending problematic cultural traditions, such as Black Pete.

The reparation claims by the CARICOM were taken up by various Caribbean reparation activists across the diaspora; leading to the formation of the European Reparation Commission (ERC) of the European Network of People of African Descent (ENPAD), ${ }^{20}$ committed to support the CARICOM claim in Europe. ENPAD includes also regional organisations such as the Dutch civil society organisation D'HERO. They all were present at the International Reparations Summit in New York, on 9-12 April 2015, organized by the Institute of the Black World 21st Century ${ }^{21}$ to connect also with the National African American Reparations Commission (NAARC) ${ }^{22}$ and the National Coalition of Blacks for Reparations in America (N'COBRA). ${ }^{23}$ While this was a key event for the building of global communicative networks, it became evident that different interests were involved: the interests of the European diaspora were not the same as those of the Caribbean or US based initiatives, nor again as those expressed by representatives of indigenous communities, who felt neglected or mis-represented by all parties. ${ }^{24}$

\section{Repair by Others and Self-Repair}

'To learn to talk about reparations' was what memory and reparation activist Kenneth Donau from D'HERO identified as being one of the key challenges within the Dutch context. Language is a crucial part of the problem of talking about recognition: 'there is no adequate word in Dutch that grasps our struggle for reparations'. Donau, a freelance radio presenter, knows about the power and perils of language:

Reparations in Dutch (herstelbetalingen) has 'paying money' understood within the term, narrowing down the idea of repair right from the beginning and causing resistance by those unwilling to pay. The alternatives, 'restitution' and 'legal redress' (rechtsherstel) or 'rehabilitation' (eerherstel), focus on the past and miss out the aspect of future. There is no equivalent term in Dutch to cover all of what Wiedergutmachung stands for. And what all these terms have in common, is that 
they miss out on the notion of 'redistribution,' which is key to our reparation

desire. $^{25}$

30 UK lawyer and PARCOE representative, provides important insights. After starting off with some common misconceptions about reparations, such as the centrality of the notion of money (labelled 'the Americanization of the reparation debate') and promising developments in international law (such as the Basic Principles for Reparations in the VN framework ${ }^{28}$ ), Stanford-Xosai elaborated on a comprehensive notion of repair derived from multiple African traditions, discussing reparations in social, political, psychological and cultural terms, reparations as a social movement, advocating for a more holistic framework in Europe. She then made the distinction between two ideological strands in thinking about reparations: reparations as state action linked to nationalism, and as a tool to rebuild communities and oneself. 'We talk about the external and the internal reparation. What others owe us and processes of self-repair. The self-repair will give us the power, the unity, the power. This makes it easier to make those demands to others.' From her view, the CARICOM reparation claims are mainly linked to nation building (solidarity building in the Caribbean and the restructuring of relationships between CARICOM countries and the former European colonial powers), while the reparation claims in the Rastafari tradition are linked to community building, described as rediscovering one's own humanity, emancipation, and spiritual self liberation-or in the terms of dignity, agency, and wellbeing. Both are seen as crucial as self-repair is seen as a prerequisite for external reparations. ${ }^{29}$ We learn from this Rastafari perspective that both, enslavers and enslaved, have to do selfrepair first, as healing is about getting engaged with oneself to get engaged with the other. This also means that it is not just the state providing reparations, but communities as well. The relational and participative characters of reparations are crucial: a process by and for the people.

\section{First Equality then Dialogue}

Dutch memory and reparation activists identify with this much broader notion of repair: while reparations are generally framed as reparatory instruments designed to strengthen a community, here the idea is that a strong Surinamese and Caribbean community is a precondition before serious reparation talk can start ('The pressure of survival is so high that people pay little attention to the bigger picture'). For Kenneth Donau, self-repair is seen as the essential component for achieving more equality between partners: 'Now it's often about: tell me about your pain. You can similarly say: tell me about your guilt. That's not a good conversation either. You have to be equal partners in the conversation'. It needs an eye-to-eye conversation, otherwise he is 
convinced that the dialogue approach on recognition questions-which in recent years has developed into a key justice instrument for local and national governments-'is doomed to fail' ${ }^{30}$ Both sides have to first educate themselves about the history and its legacy-the inferiority complex on the one hand, and the guilt complex on the otherbefore 'taking responsibilities' can be discussed. Therefore the recognition of the history of slavery is imperative: 'This recognition means that our claim is not a case of "asking for a favour", but it is more to do with "I am entitled to an equal share". The primary aim is the restoration of rights and a self-confident black community.' This is a conviction that D'HERO as an organisation stands for, explains front man Regillio Vaarnold: 'A strong sense of identity creates a self-confident black community. If we achieve that, reparations will not even be necessary anymore. Then everyone will have an equal chance to succeed and nothing will stand in the way of black success. That's why money is not the most important thing. ${ }^{31}$ While money is needed to invest in structural improvements for nourishing a group identity and participation on equal terms, and although money is a key term in the public debate on how to acknowledge the slavery past, it is not the money as such that should be seen as reparation.

While reparations within the larger public arena are associated mainly with 'numbers,' for memory activists such as Mitchell Esajas and Jessica de Abreu from The Black Archives in Amsterdam, a key voice of the Dutch Black community, the debate is one about justice in a much broader sense: 'You can do apology and recovery in all kinds of ways. Adapting educational curricula, abolishing Black Piet, tackling racism in the labour market-these are all forms of recovery. Perhaps extra care for people, who experience the mental effects of racism'. ${ }^{32}$ The Black Archives embody this comprehensive notion of repair (including backward and forward-looking repair) by being an institution that includes an archive and library for Black history to decolonize knowledge, as well as functioning as a social platform acting at the forefront of the Black Lives Matter movement for a more equal and just society ('that everyone gets the chance to get the most out of themselves'). For Esajas 'reparatory justice' is not personal but institutional: when museums acknowledge their role in reproducing racial images and ideologies; or governments acknowledge the wealth-gap at collective level. 33

\section{From Material Repair to Restoring Rights}

Paradigmatic for this struggle around a broader notion of reparation was the speech of Barryl A. Biekman, a renowned Pan-African activist and head of the Platform Dutch Slavery Past in the opening ceremony of the UN Decade for People of African Descent (2014-2024) in December 2014. When she described the UN-decade as a 'Reparation Decade,' observers described this as 'raising the red flag,' referring back to the intense debates about reparations for slavery and colonialism at the World Conference against Racism in Durban in 2001, where slavery was acknowledged as a crime against humanity.

Biekman claimed that 'Reparation is not limited to material repair, but something more fundamental relating to restoring every aspect of the rights of people of African descent'. ${ }^{34}$ In her speech she reflected on the three pillars formulated in the UN resolution: recognition (of slavery), justice (no more racism/discrimination), and development (equal opportunities to redress economic inequality). ${ }^{35}$ These ideas shaped 
the Dutch government's subsequent approach to addressing racism. Prepared in roundtable meetings with community members, the Ministry established two funds, one for funding social projects (to contribute to the empowerment and inclusion of people of African descent), the other for funding cultural projects (the increase of knowledge and awareness of the history of slavery, colonialism and migration; the cultural heritage of people of African descent; and the consequences of prejudice and racism in Dutch society). ${ }^{36}$

Despite the government's engagement with the UN resolution, human rights lawyer Regillio Vaarnold from D'HERO was disappointed by its implementation. In his view the resolution 'degenerated into development aid on a micro level,' micro-finance for small projects, following a 'divide and rule' tactic via exclusive prize-winning settings, instead of investing in projects that help a community to flourish by pushing structural development and transformation.

Money is mainly allocated to projects run by organisations that have not brought structural solutions to the current situation of people of African descent in the past and are unlikely to do so in the future. [...] A few tons a year, that's it. What do you do with it? You organise the Keti Koti Festival on 1 July, a few exhibitions, the Black Achievement Month.....

Despite this well-developed thinking on reparations within the Dutch activist communities, both in the public debate about 'how to address the Dutch slavery past' and in party programmes, ${ }^{38}$ the question whether 'The Dutch government should apologise for the slave trade in the past' is most dominant. Reparations do not figure prominently. Although structural racism has become a more widespread topic in politics, it is not visible in the measures that are taken. As a recent survey (2021) ${ }^{39}$ shows, most Dutch people (56\%) believe that their country played a 'serious' role in the history of slavery, but only $31 \%$ support an apology or feel the need for more historical research. Those with a Surinamese or Antillean background are in favour of an apology (70\%) and two thirds of the Turkish and Moroccan Dutch population are. of the 31\% supporting an apology, $17 \%$ demand financial compensation, which is $5 \%$ of the whole population. What the survey reflects foremost is the lack of broader notions of justice in public debates (as if there are no other options).

While most white Dutch people recognise this shared past, they feel (according to this survey) no personal involvement and even less responsibility. Here the public conversation about the slavery past often goes no further than whether or not to apologize; this mirrors the conversation about racism that also often goes no further than whether or not racism is a problem and whether or not racism should be fought. ${ }^{40}$ In the words of Urwin Vyent, Director of NiNsee: the racism debate remains far too superficial, being about 'Black Piet' rather than about 'how the history of slavery still affects today's society, our relationships'. ${ }^{41}$ This alerts us to the fact that both debates on reparations and on racism fail to bring about processes of social change. If we turn to Michel-Rolph Trouillot's Silencing the Past (1995): what remains silenced or 'unthinkable' in this survey about reparations?

\section{Different Understandings of Justice}

Reading the debate in the Netherlands on its slavery past, as described above, through the lens of Lisa J. Laplante's continuum justice model allows us to identify different justice 
claims by the parties involved, but also to see how reparation claims have developed over time: what do Dutch/Caribbean reparation activists mean by repair when claiming reparations for colonial wrongs?

In the late 1990s, the Surinamese and Antilleans communities followed a more narrow reparative and restorative approach (identity building and personal healing on microlevel), together with a calculation of specific past damages around slavery and the slave trade (Zunder 2010). This approach developed into a struggle for more transformative justice, mainly influenced by the Black Lives Matter Movement, the CARICOM claims and the UN-decade. First, this included the civic justice approach (macro-reconciliation between citizens and state), calling for institutional responses that would indicate structural changes granting inclusion to the hitherto marginalised, addressing equal representation in politics and media and equal opportunities in education and in the job and housing market. Second, it also included the socioeconomic justice approach, prioritizing (re-)distribution (independent from causality) as a way of reducing substantial socioeconomic inequalities between ethnicities, and addressing attitudes towards race, class, gender and nationality that create those inequalities.

While the narrow debate in Dutch politics and media on 'apologies' fitted the initial restorative approach advocated by Surinamese and Antillean communities in the 1990s, this is now experienced as outdated and inappropriate. In its narrowness, it undermines the much broader aims of repair that circulate in those communities. Their struggle is structural rather than symbolic; it moves from the language of symbolic and (monetary) reparation towards the notion of (social) repair; it combines a backwardlooking and a forward-looking approach, addressing human rights violations of the past and structural inequalities to be addressed in the present. As Maeve McKeown's analysis of the CARICOM 10-point plan has exposed so clearly, there are 'forwardlooking goals' aiming at socio-structural change, while the justifications for reparations are 'fundamentally backward-looking,' stressing the crimes committed by European states against humanity (McKeown 2021: 5). According to McKeown the 'backwardlooking liability model identifies European states as bearing outstanding obligations for repair,' while European citizens bear 'a forward-looking, non-blameworthy political responsibility' (2021: 21).

The above findings suggest that reparation claims are less about a specific product than about a social process of relation-building. The notion of 'social repair' challenges and extends our current imagination about what justice for historical wrongs is about, but -as I would like to argue-it will ironically also make reparations more acceptable by larger parts of Dutch society. It avoids the narrow 'blame-and-guilt' framework associated with reparations in politics and the media, which creates the problem of acceptance in the first place. The notion of social repair might instead recognize a joint struggle for a more fair and equal society.

\section{Conclusion: From Reparation Towards Repair}

The centrality of social repair in transformative justice thus begs the question of how to organize the building of such social relations. Participation is seen as a key variable in transformative reparations:

the potential for shifts in agency and power relations around reparations reside mainly in the fact that reparation campaigns usually evolve over time, from below, 
as a result of civil society and victim/survivor mobilization and in the face of official opposition. Herein lies the possibility for participation, constituency building and the acquisition of new skills, and fresh patterns of engagement with the state through and beyond reparation campaigns (Gready \& Robins 2014: 358). participation,' a form of participation that 'engages with but transforms victimhood' (ibid.).

However, the act of restoring a relationship is also the act of restoring relations of power. Recognition questions are deeply entangled in questions of power, with a high risk that they will affirm rather than transform existing power hierarchies. How to account for the racialised legacies of colonialism and slavery without reproducing a racialised discourse in a politics of recognition (Jones 2020: 281-3)? How to avoid the 'politics of compassion,' which establish a compassionate subject and a suffering object, repeating hierarchical relationships between the 'saviour with good intentions' and those 'who need to be saved,' and reproduce positions of superiority and inferiority (Balkenhol 2016: 288)? How to deconstruct the "logic of "who acknowledges" and "who is acknowledged", of "who gives" and "who receives", which in itself carries the signature of historical violence and power relationships' (Immler 2021b: 267)? Over the last two decades, there has been an increase in gestures of recognition by the Dutch state and many dialogue initiatives were started-the question remains, however, of what substantial changes have been made.

The recent launch of a report ('Chains of the Past') by the Advisory Board Dialogue Group on the history of slavery, presented on 1 July 2021, underlines such shortcomings. They advised the government to 'acknowledge the slavery past as a crime against humanity,' apologize at national level, establish a national museum, a national day of remembrance, encourage more research and education on the history of slavery and its legacies, and set up a Kingdom Fund for structural and sustainable financing of rehabilitation measures including the Caribbean islands. ${ }^{42}$ Those recommendations appear to be comprehensive. However, if one applies Laplante's justice categories, one realizes that civic and socio-economic justice, and means of combatting discrimination and racism on an institutional level, are yet again not at the forefront of the discussion.

The Dutch debate on slavery has shown that reparation theory is essential in identifying what kind of justice claim is being made and then evaluating whether this claim is being answered. Recognition claims are too often answered by standard recognition procedures, creating disappointments, since claimants feel that they were not heard. Laplante (2013: 79) helps us to see that if these justice goals of social repair are not clearly articulated and addressed, we would be likely to see the frustrations of memory politics and memory activists, who 'may compromise the overall justice project,' thus jeopardising the potential for a transformative outcome. The notion of social repair, as proposed in this article, foregrounds a joint struggle benefitial for society as a whole. 


\section{BIBLIOGRAPHY}

ARAUJO, Ana Lucia, 2017. Reparations for Slavery and the Slave Trade: A Transnational and Comparative History, London, Bloomsbury Academic.

BALKENHOL, Markus, 2016. 'Silence and the politics of compassion. Commemorating slavery in the Netherlands,' Social Anthropology, No. 24/3, pp. 278-93.

BECKLES, Hilary, 2013. Britain's Black Debt: Reparations for Caribbean Slavery and Native Genocide, Kingston, University of West Indies Press.

BROOKS, Roy L., 2006. Atonement and Forgiveness: A New Model for Black Reparations, Oackland, University of California Press.

BROPHY, Alfred, 2006. 'Reconsidering Reparations,' Indiana Law Journal, No. 81/3, pp. 811-50.

CAIN, Artwell, 2017. Social Mobility of Ethnic Minorities in the Netherlands: The Peculiarities of Social Class and Ethnicity, Delft, Eburon.

CARICOM REPARATIONS COMMISSION, 2014. 10-point Reparation Plan. Available

online: caricomreparations.org/caricom/caricoms-10-point-reparation-plan/ [last accessed, August 2021].

DALY, Erin, 2002. 'Transformative Justice: Charting a Path to Reconciliation,' International Legal Perspectives, No. 12, pp. 79-183.

DE GREIFF, Paul, 2006. 'Justice and reparations,' in Paul de Greiff (ed.), The Handbook of Reparations, Oxford / New York, Oxford University Press, pp. 451-78.

DE GREIFF, Paul \& Rogers DUTHIE, 2009. Transitional Justice and Development. Making Connections, New York, Social Science Research Council.

ESSED, Philomena \& Isabel HovING, 2014. Dutch Racism, Brill, Rodopi.

EYERMAN, Ron, 2001. Cultural Trauma. Slavery and the Formation of African American Identity, Cambridge / New York, Cambridge University Press.

FASSIN, Didier \& Richard RECHTMAN, 2009. The empire of trauma: An inquiry into the condition of victimhood, Princeton / Oxford, Princeton University Press.

FATAH-BLACK, Karwan, 2020. 'Waar de ketenen begonnen te breken: de in Nederland vergeten afschaffing van 1793,' Keti Koti lezing, Amsterdam, Nationaal Instituut Nederlands Slavernijverleden en Erfenis, 30 June. Available online: www.dipsaus.org/exclusives-posts/ 2020/7/2/waar-de-ketenen-begonnen-te-breken-de-in-nederland-vergeten-afschaffing-van-1793 [last accessed, August 2021].

GREADY, Paul \& Simon RoBINS, 2014. 'From Transitional to Transformative Justice: A New Agenda for Practice,' International Journal of Transitional Justice, Vol. 8, No. 3, pp. 339-61.

GREADY, Paul \& Simon RoBINS, 2018. From Transitional to Transformative Justice, Cambridge / New York, Cambridge University Press.

GUADELOUPE, Francio, 2014. 'Reparaties als een hedendaagse uiting van de permanente revolutie: een standpunt,' Bijdragen en Mededelingen betreffende de Geschiedenis der Nederlanden, No. 129/4, pp. 106-17. 
HAMBER, Brandon, 2000. 'Repairing the Irreparable: Dealing with the Double-Binds of Making Reparations for Crimes of the Past,' Ethnicity and Health No. 5-3/4, pp. 215-26.

HONDIUS, Dienke, Nancy Jouwe, Dieneke STAM, Jennifer Tosch \& Annemarie DE WILDT, 2018 [2014]. Amsterdam Slavery Heritage Guide, Arnhem, LM Publishers.

IMMLER, Nicole, 2021a. 'Het slavernijverleden als erfenis,' Wijsgerig Perspectief, No. 1, pp. 24-33. Available online: www.filosofie.nl/het-slavernijverleden-als-erfenis/ [last accessed, August 2021]. IMMLER, Nicole, 2021b. 'Colonial history at court: Legal decisions and their social dilemmas,' in Jacqueline Bhabha, Margareta Matache, Caroline Elkins (eds.), Time for reparation? Addressing state responsibility for collective injustice, Philadelphia, University of Pennsylvania Press, pp. 241-67. JONES, Guno, 2012. 'De Slavernij is Onze Geschiedenis (niet): Over de Discursieve strijd om de Betekenis van de NTR- Televisieserie De Slavernij,' BMGN. Low Countries Historical Review, No. $127 / 4$, pp. 56-82.

JONES, Guno, 2020. 'The Shadows of (Public) Recognition. Transatlantic Slavery and Indian Ocean Slavery in Dutch Historiography and Public Culture,' in Alicia Schrikker \& Nira Wickramasinghe, Being a Slave. Histories and Legacies of European Slavery in the Indian Ocean, Leiden, Leiden University Press, pp. 269-93.

LAMBOURne, Wendy, 2009. 'Transitional Justice and Peacebuilding After Mass Violence,' International Journal Transitional Justice, No. 3, pp. 28-48.

LAPLANTE, Lisa J., 2013. “The Plural Justice Aims of Reparations," in Susanne Buckley-Zistel et al. (eds.), Transitional Justice Theories, London, Routledge, pp. 67-84.

LAPLANTE, Lisa J., 2015. 'Just Repair,' Cornell International Law Journal, No. 48, pp. 513-78.

LU, Catherine, 2017. Justice and Reconciliation in World Politics, Cambridge / New York, Cambridge University Press.

LUNDY, Patricia \& Mark McGovern, 2008. 'Whose Justice? Rethinking Transitional Justice from the Bottom-Up, Journal of Law and Society, No. 35/2, pp. 265-92.

MCAULIFFE, Padraig, 2017. 'Transitional justice's transformative turn: how we got here, what we know and what we don't,' in Padraig McAuliffe, Transformative transitional Justice and the Malleability of Post-Conflict States, London, Edward Elgar, pp. 30-90.

MCEVOY, Kieran \& Lorna MCGREGOR (eds.), 2008. Transitional Justice from Below. Grassroots Activism and the Struggle for Change, Oxford, Hart Publishing.

MCGONIGLE LEYH, Brianne \& Julie FRASER, 2019. 'Transformative Reparations: Changing the Game or More of the Same?,' Cambridge International Law Journal, No. 8/1, pp 39-59.

MCKEOWN, Maeve, 2021. 'Backward-looking Reparations and Structural Injustice,' Contemporary Political Theory. DOI: https://doi.org/10.17863/CAM.62192.

MILLER, John \& Rahul KUMAR (eds.), 2007. Reparations: Interdisciplinary Inquiries, Oxford, Oxford University Press.

MUTUA, Makau, 2015. 'What Is the Future of Transitional Justice?,' International Journal of Transitional Justice, No. 9/1, pp. 1-9.

NEUMAnN, Klaus \& Janna THOMPSON, 2015. 'Introduction. Beyond the Legalist Paradigm,' in Klaus Neumann \& Janna Thompson, Historical Justice and Memory, Madison, University of Wisconsin Press, pp. 3-24. 
OLSEN, Tricia D., Leigh A. PAYNE \& Andrew G. REITER, 2010. Transitional Justice in Balance: Comparing Processes, Weighing Efficacy, Washington, D.C., United States Institute of Peace Press.

OOSTINDIE, Gert, 2011. Postcolonial Netherlands. Sixty-five Years of Forgetting, Commemorating, Silencing, Amsterdam, Amsterdam University Press.

scotT, David, 2014. 'Preface: Debt, Redress,' Small Axe, No. 18/43, pp. vii-x.

SHEPERD, Verena, 2018. 'Past Imperfect, Future Perfect? Reparations, Rehabilitation,

Reconciliation,' The Journal of African American History, No. 103/1, pp. 19-43.

STANFORD-XOSEI, Esther \& Kofi MALUWI KLU, 2013. 'An open letter to the heads of government of the Caribbean Community (CARICOM),' Caribbean News Now, 14 July. Available

online: www.alainet.org/en/active/65675 [last accessed, August 2021].

STRECKER, Amy, 2017. 'Indigenous land rights and Caribbean reparations discourse,' Leiden Journal of International Law, No. 30, pp. 629-46.

THOMS, Oskar N.T., James RON \& Roland PARIS, 2010. 'State-Level Effects of Transitional Justice: What Do We Know?,' International Journal of Transitional Justice, No. 4/3, pp. 329-54.

TROUILLOT, Michel-Rolph, 1995. Silencing the past: Power and the production of history, Boston, Mass., Beacon Press.

WEKKER, Gloria, 2016. White Innocence. Paradoxes of Colonialism and Race, Durham, NC, Duke University Press.

YEPES, Rodrigo U., 2009. 'Transformative Reparations of Massive Gross Human Rights Violations: Between Corrective and Distributive Justice,' Netherlands Quarterly of Human Rights, No. 27, pp. 625-47.

ZUNDER, Armand, 2010. Herstelbetalingen. De 'Wiedergutmachung' voor de schade die Suriname en haar bevolking hebben geleden onder het Nederlands kolonialisme, Den Haag, Amrit Consultancy.

\section{NOTES}

1. My thanks to all who participated in this research, particularly the interviewees who shared their knowledge with me, and without whom this research would have not been possible. The article is based on qualitative interviews by the author with multiple actors in the field of memory and reparation activism regarding the slavery past in the Netherlands; fieldwork took place at commemoration and reparation events between 2011-2018. Some of the interviews are publicly archived at DANS: Data Collection Narrated Injustice-Casus 3: Het slavernijverleden (doi.org/10.17026/dans-ze8-yg84). This research was supported by a Marie Curie Fellowship for the Project Narrated (In)Justice at the NIOD Institute for War, Holocaust and Genocide Studies (NIOD).

2. Others have asked for more debate on matters of application and conceptual challenges (Mutua 2015).

3. For an overview of the development of transformative theories challenging the traditional idea of reparations, focused on human rights and international criminal bodies that deal with reparations, see McGonigle Leyh \& Fraser 2019: 50.

4. I follow here her 2013 publication and her categorization of the Transitional Justice literature. While such typologies easily generate the assumption of conceptual clarity, 
Laplante stressed herself that the social reality of Transitional Justice processes is more 'messy' (Laplante 2015: 577), as different actors engage with their multiple visions of justice: it is a process of participation and contestation, exchange and overlap.

5. More recent examples of reparation provided by particular companies, families, universities, and newspapers show however that it is possible to take some specific responsibility even after several generations have passed.

6. Brooks pinpointed his argument in his opinion piece 'Reparations aren't about money': $\quad$ www.twincities.com/2019/04/28/roy-l-brooks-reparations-arent-aboutmoney/. All weblinks are valid in August 2021.

7. NiNsee was viewed as a 'gesture' towards the Black community; however it lacks structural funding (Jones 2020: 293).

8. Projects such as mappingslavery.nl, mapping the traces of slavery in Dutch cities, upon which Slavery Heritage Tours were developed (Hondius et al. 2018 [2014]).

9. There were various organisations such as the Afro European Women's Movement Sophiedela and others involved in the first and second feminist wave, or the postcolonial emancipation movements that addressed anti-colonial issues before 2011, but 'race' was not a key category. For the (lack of) debate on racism see Essed \& Hoving (2014) and Wekker (2016).

10. Interview with Marcel van Kanten, a participant in the Keti Koti dialogue tables in Amsterdam in July 2020, by Hester Buwalda (see Immler 2021a).

11. For this reason a conference explored the nature of the concept: 'Cultural Trauma? Transatlantic slavery in perspective,' Amsterdam City Archive, 30 June 2021. www.europa-nu.nl/id/vj8759v6ilxz/agenda/symposium_cultureel_trauma_trans? ctx=vhkfc4t17nrt.

12. A history long silenced by historiography outside Haiti: in the words of the Haitian historian Michel-Rolph Trouillot: 'resistance and defiance did not exist, since to acknowledge them was to acknowledge the humanity of the enslaved' (Trouillot 1995: 83). Trouillot identified two discursive tropes silencing the Haitian Revolution; 'formulas of erasure' by calling the revolution something else, and 'formulas of banalization' by trivializing the matter and therefore its significance (p. 96).

13. See footnote 28 .

14. www.un.org/en/observances/decade-people-african-descent. The Decade's theme is recognition, justice, and development: to encourage states to implement comprehensive political measures to ensure human rights protections and equity for people of African descent. This includes rights to development, measures against poverty, and access to basic goods such as health care, education, housing, and employment.

15. In their adopted resolution 68/237. Speech by Flavia Pansieri, Deputy High Commissioner for Human Rights at the Launch of the International Decade for People of African Descent, Geneva, 16 December 2014; this recognised that people of African descendant were 'marginalized, excluded and among the poorest communities' whose human rights must be promoted and protected: www.ohchr.org/EN/NewsEvents/ Pages/DisplayNews.aspx?NewsID=15432\&LangID=E.

16. www.un.org/WCAR/durban.pdf. Durban provided the first international platform for Caribbean activists to present their proposals for reparations for slavery and colonialism to former colonial powers. While largely ignored by the US, African and 
European governments, this neglect unified and inspired the CARICOM movement (Beckles 2013).

17. caricomreparations.org/caricom/caricoms-10-point-reparation-plan/

18. www.un.org/pga/101214_address-beckles/ (10 December 2014). Beckles: 'We felt never so proud in our pan-African consciousness. There is a global African reparation movement that binds us together as crimes against humanity was global in its consequences'.

19. Verene Sheperd in her opening speech at the conference 'Repairing the Past, Imagining the Future: Reparations and Beyond,' University of Edinburgh, 5-7 November 2015. See also Sheperd 2018.

20. ENPAD currently consists of 20 member organizations in nine European countries, engaging in grassroots mobilization, political advocacy, and communication to raise public awareness of anti-black racism in Europe, advocating for national action plans against racial discrimination and for an $\mathrm{EU}$ framework for people of African descent.

21. ibw21.org/national-international-reparations-summit-registration-form-2015/.

22. reparationscomm.org/reparations-plan/.

23. www.ncobraonline.org/.

24. For details of some of the problems see Strecker 2017; for an overview of the various reparation movements, see Araujo 2017.

25. Interview by author, Amsterdam 14 June 2018 (DANS: Narrated Injustice collection, doi.org/10.17026/dans-z28-3f33).

26. In an open letter to CARICOM's Reparation Commission representatives of PARCOE demand more attention for the African Diaspora living in Europe, with 'familial connections in the Caribbean', to make sure that the CARICOM claims 'are in accordance with the will and aspirations of the various stakeholders and communities... within and beyond the Caribbean' (Stanford-Xosei \& Maluwi Klu 2013).

27. Esther Standford-Xosai, Masterclass, VN Reparation Framework, 11-12 September 2015, The Hague.

28. The Basic Principles and Guidelines on the Right to a Remedy and Reparation for Victims of Gross Violations (Basic Principles) were adopted by the UN in 2005, setting a new international standard for reparations in international law. Although not a convention but soft law and thus not legally binding-and the right cannot be put into practice as no money is available-this consensus between governments is seen as a valuable framework for NGOs as the Basic Principles symbolise an agenda. (see UN General Assembly Resolution 60/147; undocs.org/A/RES/60/147. This UN reparation framework distinguishes 5 principles of reparations: restitution (to restore the original situation), compensation (for any economically accessible damage), rehabilitation (facilitating cohesion, via medical and psychological care as legal and social services), satisfaction (all measures making people feel seen and satisfied), guarantees of non-repetition (never again, stop the continuum via reforms in in the security, judiciary, institutional spheres; one cannot repair as long as harm continues).

29. While the CARICOM claims conceptualize reparation as development between states, grassroots-organisations such as PARCOE question the existing nation-state structures in the Caribbean as a consequence of colonial and neo-colonial relations, seeking themselves new models of trade, economics and society; and advocating a pan- 
African perspective on Global Justice. Those radical traditions have influenced the 10point plan, which is however less radical: 'The CRC's framing of compensation and repair aligns with a Pan Africanist ontology of justice and [...] their call for "The right to development" is in conversation with a Rastafarian ontology of repair,' but the 10point plan, as Zaira Simone says, 'does not advocate for the abolition of capitalism, but rather for equity through reparations'. The CRC aims at regional development and 'their advocacy is largely pursued through diplomacy,' which means privileging institutional action and representation over grassroots activism. I follow here Zaira Simone, who, on our panel 'Epistemologies of Repair' presented a paper on 'Caribbean Visions of Repair' (publication forthcoming) at the workshop 'On the Possibility and the Impossibility of Reparations for Slavery and Colonialism, Columbia University, NYC, 24 May 2021. By way of amplification one could say that PARCOE accuses the CARICOM of stabilizing the system by revolting within the given framework, instead of questioning the system one operates in. For a position paper of the Rastafari-community in Barbardos, see http://rastaites.com/position-paper-of-the-rastafari-community-inbarbados/.

30. Interview by the author, Amsterdam 14 June 2018 (DANS: Narrated Injustice collection, doi.org/10.17026/dans-z28-3f33).

31. Interview by Dannis L'Ami, 24 November 2016; decorrespondent.nl/5736/innederland-herdenken-we-de-slavernij-met-een-prijsvraag/492334112952-e8f959c3.

32. Interview by Thijs Niemantsverdriet: www.nrc.nl/nieuws/2020/12/28/als-het-omracisme-gaat-zeggen-mensen-altijd-meteen-ingewikkeld-a4025401. See also theblackarchives.nl.

33. Interview by Joy Chung, Amsterdam, 28 June 2018 (DANS: Narrated Injustice collection, doi.org/10.17026/dans-xqn-4cdc).

34. www.un.org/pga/69/101214_statement-biekman/ (14 December 2014). Her claim is detailed: 'The Decade must become a framework to address the concentration of misery and disadvantages which people of African descent face everywhere they live: poverty, racial discrimination and lack of access to human rights \& their institutions, high rates of unemployment and imprisonment, vulnerability to violence and lack of access to justice, lack of access to good education, healthcare, housing, multiple forms of discrimination, and political and economic marginalization and stigmatization'.

35. www.rijksoverheid.nl/onderwerpen/discriminatie/de-decade-in-nederland.

36. They also commissioned inventory studies on the position of people of African descent in Dutch society and the inclusion and exclusion processes at stake (Cain 2017).

37. https://decorrespondent.nl/5736/in-nederland-herdenken-we-de-slavernij-meteen-prijsvraag/492334112952-e8f959c3. D'HERO supports a local party Ubuntu Connected Front, advocating for a comprehensive reparatory justice programme, including ethical, historical, educational, social, economical, cultural, and financial redress: ubuntuconnectedfront.com/wp-content/uploads/2021/01/THEMA-FOCUS-OPZWART.pdf.

38. Riffy Bolder \& Vera Mulder, 'Zo denken én handelen de politieke partijen als het gaat over racisme' (This is how the political parties think and act when it comes to racism): https://decorrespondent.nl/12053/zo-denken-en-handelen-de-politiekepartijen-als-het-gaat-over-racisme/4764201194258-186111be. 
39. Eric Brassem, 'Nederlanders vinden slavernijverleden ernstig, maar achten excuses niet op zijn plaats' (Dutch find slavery past serious, but consider apologies inappropriate), 12 February 2021: www.trouw.nl/nieuws/nederlanders-vindenslavernijverleden-ernstig-maar-achten-excuses-niet-op-zijn-plaats bacd9e55/.

40. https://decorrespondent.nl/12053/zo-denken-en-handelen-de-politieke-partijenals-het-gaat-over-racisme/4764201194258-186111be.

41. Interviewed by Harrie Salm, 1 July 2020: www.trouw.nl/binnenland/hetslavernijverleden-drukt-nog-altijd-een-stempel-op-de-samenleving-zegt-organisatorherdenking b2e82cof/.

42. www.rijksoverheid.nl/documenten/rapporten/2021/07/01/adviescollegedialoogroep-slavernijverleden-presenteert-eindrapport-ketenen-van-het-verleden. As Hilary Beckles put it in his Keti Koti lecture (30 June 2021, NiNsee) on Reparations, it needs the awareness and the recognition that there is a problem first, before instruments that are reparatory can be offered. Therefore an apology from the Dutch state is considered as crucial, before 'a more effective moral order' can be established. Beckles asked the Dutch government to take the lead in reparations for slavery on account of their historical role as being the first to develop the slave trade as a corporate enterprise. See www.youtube.com/watch?v=uWFe4t3FPZU.

\section{ABSTRACTS}

While Transitional Justice instruments have been implemented in plenty of post-conflict cases, what little knowledge we have about the effects of these measures shows contradictory findings, indicating that they are often ambiguous and disappointing. Consequently the last decade has seen a specific call for a 'new agenda for practice' proposing a transition from Transitional Justice to Transformative Justice. It is a request by scholars such as Paul Gready and Simon Robins (2014) to develop from the bottom-up a concept of justice that is more 'transformative,' specifically challenging 'unequal and intersecting power relationships and structures of exclusion at both the local and the global level'. This article contributes to this consideration by exploring the Dutch debate on its slavery past with the following question: how could reparations-fundamental in the debate around the acknowledgment of the slavery past-facilitate transformative justice? In the Netherlands over the last decade, memory and reparation activists seeking recognition for slavery and the transatlantic slave trade have been influenced by two major events; the 10-point reparation claim put forward by the Caribbean CARICOM countries against the formerly colonizing powers in Europe (2013), and the UN-International Decade for People of African Descent (2015-2024). This article describes the reparation claims articulated by various groups in and outside the Netherlands addressing the slavery past of the Dutch and some of the institutional responses. Reparations have gained little conceptual attention in transitional justice scholarship, and in investigating the concept of reparation we refer to Lisa Laplante's (2013) dictum, which is that 'Reparations can and should be viewed through a lens of justice'. Laplante made an important intervention in the field by asking which reparations contribute to what kind of justice. Reading the Dutch question through the lens of Laplante's continuum justice model (2013) makes it possible to identify different justice claims made by interested and affected 
parties. Laplante's model ranges from a narrow (minimalist) to a broader (maximalist) conceptualisation of justice; distinguishing four types of justice aims: reparative justice, restorative justice, civic justice and socio-economic justice. All four types are relevant when considering the various options a government and a society have in dealing with (historical) injustice. The empirical findings suggest that current reparation claims in Afro-Caribbean and Surinamese communities are less about a specific product (such as an apology or reparations) but rather about a social process of relation building (such as addressing structural injustices). This notion of 'social repair' challenges and extends our current understanding of what justice for historical wrongs is about, but-as is argued in this article-it will at the same time also make reparations more acceptable to larger parts of Dutch society. It avoids the narrow 'blame-and-guilt' framework associated with reparations in politics and the media, which exacerbates the problem of acceptance in the first place.

The key arguments in this article firstly show that reparation theory is essential in identifying the kind of claims for justice that are being made, and secondly evaluate whether those claims are being addressed. Laplante helps us to see that if these justice goals of social repair are not clearly articulated and addressed, we would be likely to disappoint memory politics and memory activists, who 'may compromise the overall justice project,' thus jeopardising the potential for a transformative outcome.

The notion of social repair, as proposed in this article, recognizes a joint struggle for a more fair and equal society.

Tandis que les instruments de la justice transitionnelle ont été mis en place dans de nombreuses situations postconflictuelles, les rares études portant sur les effets de ces mesures montrent des résultats contradictoires - les effets sont souvent ambigus et décevants. C'est pourquoi la décennie écoulée a vu se mettre en place la théorisation du passage de la justice transitionnelle à la justice transformative. Des chercheurs comme Paul Gready et Simon Robins (2014) ont souligné combien il est important de developer, depuis les pratiques de terrain, un concept de «justice transformative». Ce concept a pour fonction spécifique de remettre en question «les multiples relations de domination ainsi que les structures d'exclusion qui s'exercent à la fois au niveau local et global » (Gready \& Robins 2014 : 340). Le présent article vise à contribuer à ce renouvellement en explorant le débat qui a lieu aux Pays-Bas à propos du passé esclavagiste du pays à travers la question suivante : comment les réparations - fondamentales dans ce débat pourraient-elles faciliter la justice transformative ? Aux Pays-Bas, les activistes de la mémoire et des réparations, qui demandent la reconnaissance de l'esclavage et de la traite transatlantique, ont été influencés par deux événements récents : la demande de réparations en dix points présentée par les pays du CARICOM contre les anciennes puissances colonisatrices en Europe (2013) et la Décennie internationale des personnes d'ascendance africaine proclamée par les Nations unies (2015-2024). Cet article décrit les demandes de réparations formulées par divers groupes à l'intérieur et à l'extérieur des Pays-Bas à propos du passé esclavagiste de ce pays et certaines des réponses institutionnelles qui leur ont été apportées. Dans les travaux sur la justice transitionnelle, les réparations demeurent peu théorisées ; pour étudier le concept de réparation, nous proposons d'adopter la proposition de Lisa Laplante (2013), selon laquelle « les réparations peuvent et doivent être appréhendées du point de vue de la justice ». En particulier, elle propose de se demander quel type de réparation contribue à quel type de justice. La lecture du débat néerlandais à travers la lentille du modèle de «continuum de justice » de Lisa Laplante (2013) permet d'identifier les différentes demandes de justice des parties concernées. Le modèle de Laplante distingue quatre types de conceptualisation de la justice, tous pertinents pour considérer les différentes manières qu'a un gouvernement, ou une société, de répondre aux injustices historiques, depuis une conception plus étroite ou minimaliste jusqu'à une conception plus large ou maximaliste: justice réparatrice, restauratrice, civique et socio-économique. 
L'article suggère que les demandes de réparations actuelles émises dans les communautés afrocaribéenne et surinamienne portent moins sur un objet spécifique (comme des excuses ou des indemnisations) que sur un processus social de construction de relations. Cette notion de « réparation sociale » (social repair) bouscule et élargit nos représentations actuelles sur l'objet de la justice réparatrice pour des torts historiques; en outre, l'article suggère qu'elle peut rendre l'idée de réparation plus acceptable pour de larges pans de la société hollandaise. Elle permet de dépasser le cadre étroit de «blâme et culpabilité » associé aux réparations dans la politique et les médias. L'article montre que la théorie des réparations est essentielle pour identifier le type de revendications de justice qui sont formulées, puis pour évaluer les réponses faites à ces demandes. Laplante nous permet de saisir le fait que si les objectifs de la réparation sociale ne sont pas clairement énoncés et traités, nous risquons de décevoir les politiques et les militants de la mémoire, qui "peuvent compromettre le projet de justice global», et donc le potentiel de transformation. La notion de réparation (repair), telle que proposée dans cet article, propose une lutte commune pour une société plus juste et plus équitable.

Aunque los instrumentos de la justicia transicional han sido implementados en numerosas situaciones postconflicto, los pocos estudios que abordan sus efectos muestran resultados contradictorios - a menudo ambiguos y decepcionantes. Es por eso que en la última década se ha teorizado el pase de la justicia transicional a la justicia transformativa. Investigadores como Paul Gready y Simon Robins (2014) han subrayado la importancia de elaborar, a partir de las prácticas de terreno, un concepto de "justicia transformativa". Este concepto tiene como función específica interrogar "las múltiples relaciones de dominación así como las estructuras de exclusión que se ejercen a la vez a nivel local y global" (Gready \& Robins 2014 : 340). El presente artículo se propone contribuir a esta renovación explorando el debate que tiene lugar en los Países Bajos sobre su pasado esclavista a través de la siguiente pregunta: ¿de qué manera las reparaciones fundamentales en este debate - podrían facilitar la justicia transformativa? Dos acontecimientos recientes han impactado en el quehacer de los activistas de la memoria y de las reparaciones, que exigen el reconocimiento de la esclavitud y de la trata transatlántica: el pedido de reparación en diez puntos presentado por los países del CARICOM en contra de las antiguas potencias colonizadoras europeas (2013) y el Decenio internacional para afrodescendientes proclamado por las Naciones Unidas (2015-2024). Este artículo describe las demandas de reparación formuladas por diversos grupos dentro y fuera de los Países Bajos a propósito de su pasado esclavista, así como ciertas respuestas institucionales que han sido aportadas. En los trabajos sobre justicia transicional, las reparaciones siguen estando poco teorizadas; para estudiar el concepto de reparación, nos proponemos adoptar la propuesta de Lisa Laplante (2013), según la cual "las reparaciones pueden y deben ser aprehendidas desde el punto de vista de la justicia”. Propone, en particular, interrogarse sobre qué tipo de reparación contribuye a qué tipo de justicia. La lectura del debate neerlandés, a través del prisma del modelo de "continuum de justicia" de Lisa Laplante (2013), permite identificar los diferentes pedidos de justicia de las partes involucradas. El modelo de Laplante distingue cuatro tipos de conceptualización de la justicia, todos son pertinentes para considerar las diferentes maneras que tiene un gobierno, o una sociedad, de responder a las injusticias históricas, desde una concepción más estrecha o minimalista hasta una concepción más amplia o maximalista: justicia reparativa, restaurativa, cívica y socio-económica. El artículo sugiere que los actuales pedidos de reparación emitidos por las comunidades afrocaribeñas y surinamesas no se relacionan tanto con un objeto específico (tales como disculpas o indemnización) sino más bien con procesos sociales de construcción de relaciones. Esta noción de "reparación social" (social repair) sacude y amplifica nuestras representaciones actuales respecto a saber en qué consiste la justicia por daños históricos; lo que podría contribuir a que la idea de reparación fuera más aceptable para amplios sectores de la sociedad holandesa. Permite desbordar el marco estrecho de "condena y culpabilidad" asociado a las reparaciones en 
el ámbito político y mediático. El artículo muestra que la teoría de las reparaciones es esencial para identificar el tipo de reivindicación de justicia que es formulada, y luego para evaluar las respuestas a dichas demandas. Laplante nos permite entender que si los objetivos de la reparación social no se enuncian y abordan con claridad, se corre el riesgo de decepcionar políticos y activistas de la memoria, lo que "puede comprometer el proyecto de justicia global", y por ende el potencial de transformación. La noción de reparación (repair), tal como se plantea en este artículo, propone una lucha común para una sociedad más justa y más equitativa.

Os instrumentos da justiça de transição foram implementados em muitas situações pós-conflito. No entanto, os poucos estudos disponíveis sobre os efeitos destas medidas revelam resultados contraditórios - os efeitos são muitas vezes ambíguos e dececionantes. Por isso, assistimos na última década à teorização da passagem da justiça transicional para a justiça transformativa. Pesquisadores como Paul Gready e Simon Robins (2014) realçaram a importância de desenvolver, a partir das práticas de terreno, um conceito de "justiça transformativa". Este conceito tem a função específica de questionar "as múltiplas relações de dominação assim como as estruturas de exclusão que se exercem tanto ao nível local quanto global” (Gready \& Robins 2014: 340).

Este artigo pretende contribuir para esta renovação, explorando o debate que ocorreu nos PaísesBaixos sobre o passado escravista do país através da questão seguinte : como as reparações fundamentais neste debate - poderiam facilitar a justiça transformativa ? Nos Países-Baixos, os ativistas da memória e das reparações, que exigem o reconhecimento da escravidão e do tráfico transatlântico, foram influenciados por dois eventos recentes : a exigência de reparações em dez pontos apresentada pelos países do CARICOM contra as antigas potências coloniais na Europa (2013) e o Decénio internacional das pessoas de ascendência africana proclamado pelas Nações Unidas (2015-2024). Este artigo examina as demandas de reparação formuladas por diversos grupos no interior e no exterior dos Países-Baixos referentes ao passado escravista deste país e algumas das respostas institucionais que lhes foram dadas. Nos trabalhos sobre a justiça de transição, as reparações permanecem pouco teorizadas. Para estudar o conceito de reparação, partimos da proposição de Lisa Laplante (2013), segunda a qual "as reparações podem e devem ser abordadas do ponto de vista da justiça". Ela propõe, em particular, pensar que tipo de reparação contribui para que tipo de justiça. A leitura do debate neerlandês através do modelo de "continuum de justiça" proposto por Lisa Laplante (2013) permite identificar as diferentes exigências de justiça das partes envolvidas. 0 modelo de Laplante diferencia quatro tipos de conceitualização da justiça, todos eles pertinentes para considerar as diferentes respostas de um governo ou de uma sociedade às injustiças históricas, desde uma concepção mais estreita ou minimalista até uma concepção mais larga ou maximalista: justiça restaurativa, cívica e sócioeconómica. $O$ artigo sugere que as demandas de reparações atuais emitidas pelas comunidades afro-caribenha e surinamesa não tratam tanto de um objeto específico (como desculpas ou compensações) quanto de um processo social de construção de relações. Esta noção de "reparação social" (social repair) abala e alarga as representações atuais sobre o que é a justiça por prejuízos históricos ; aliás, o artigo sugere que esta noção pode tornar a ideia de reparação mais aceitável para a maioria da sociedade holandesa. Ela permite superar o quadro estreito de "repreensão e culpa" associado às reparações na política e nos mídias. O artigo mostra que a teoria das reparações é fulcral para identificar o tipo de reivindicações de justiça que são formuladas, e para avaliar as respostas dadas a estas demandas. Laplante nos permite entender que se os objetivos da reparação social não forem claramente enunciados e tratados, corremos o risco de decepcionar políticos e militantes da memória, que "podem comprometer o projeto de justiça global", e logo o potencial de transformação. A noção de reparação (repair), proposta neste artigo, propõe uma luta coletiva para uma sociedade mais justa e equitativa. 


\section{INDEX}

Mots-clés: esclavage, réparations, histoire postcoloniale, justice transitionnelle, transformation, justice, participation

Keywords: Slavery, Reparations, Repair, Postcolonial History, Transitional Justice, Transformation, Caribbean-CARICOM, Participation

Palabras claves: esclavitud, reparaciones, historia postcolonial, justicia transicional, transformación, justicia, participación

Palavras-chave: escravidão, reparações, história pós-colonial, justiça transicional, transformação, justiça, participação

\section{AUTHOR}

NICOLE L. IMMLER

Professor of Historical Memory and Transformative Justice, University of Humanistic Studies, Utrecht, Netherlands 